\title{
Concurrent ligation of cystic duct and cystic artery versus separate ligation during laparoscopic cholecystectomy in patients with acute cholecystitis
}

\author{
Jednoczesne podwiązanie przewodu pęcherzykowego i tętnicy pęcherzykowej \\ $w$ porównaniu z oddzielnym podwiązaniem podczas zabiegu cholecystektomii \\ laparoskopowej u pacjentów z ostrym zapaleniem pęcherzyka żółciowego
} \author{
Alireza Sanei Motlagh ${ }^{5}$ \\ ${ }^{1}$ Gastrointestinal Cancer Research Center, Mazandaran University of Medical Sciences, Sari, Iran \\ 2Department of General Surgery, Mazandaran University of Medical Sciences, Sari, Iran \\ ${ }^{3}$ Educational Development Center, Mazandaran University of Medical Sciences, Sari, Iran \\ ${ }^{4}$ Mazandaran University of Medical Sciences, Sari, Iran \\ ${ }^{5}$ Deputy of Medicine, Mazandaran University of Medical Sciences, Sari, Iran
}

Nasrin Rahmani ${ }^{1}$, Mahtab Bonyadi², Sohrab Sayadi ${ }^{1}$, Siavash Moradi ${ }^{3}$, Mohammad Sadegh Zamani ${ }^{4}$,

Key words: laparoscopic cholecystectomy, concurrent ligation, separate ligation, acute cholecystitis.

Słowa kluczowe: cholecystektomia laparoskopowa, jednoczesne podwiązanie, oddzielne podwiązanie, ostre zapalenie pęcherzyka żółciowego.

\begin{abstract}
Introduction: Laparoscopic cholecystectomy as a gold standard for treatment of patients with acute cholecystitis is associated with complications. Some complications are dependent on the methods of surgery and applying clips.

Aim of the research: To compare complications following concurrent and separate ligation of cystic duct and artery and evaluate the costs of each procedure.

Material and methods: The study was designed as a prospective cohort. Patients with acute cholecystitis due to gallstones were included. They were assigned into two groups: 1) separate ligation group and 2) concurrent ligation group. Routine laparoscopic surgery was performed. For the first group, the hilum was dissected and the cystic duct and artery were ligated separately. For the concurrent group, the cystic duct and artery were ligated together. Intra-operative and post-operative data were measured. Results: A total of 122 patients were enrolled in this study. The median lengths of symptoms to surgery were 3.23 days for the concurrent group versus 3.67 days for the separate group $(p=0.004)$. There was no statistically significant difference in post-operative complications. One patient in the concurrent group had biliary colic and cholestasis due to a stone in common bile duct managed by endoscopic retrograde cholangiopancreatography. Twice as many clips were used in the separate group than in the concurrent group (six clips vs. three clips, $p \leq 0.001$ ). Further analyses revealed that operation time and costs were significantly higher in the separate ligation group.

Conclusions: The mean duration of surgery and number of clips applied for ligation were higher in the separate ligation group. Concurrent ligation seems to be associated with similar complications and therapeutic outcomes compared to separate ligation and is cost effective for replacement of the routine procedure in the future.
\end{abstract}

\section{Streszczenie}

Wprowadzenie: Cholecystektomia laparoskopowa - złoty standard w leczeniu pacjentów z ostrym zapaleniem pęcherzyka żółciowego - wiąże się z występowaniem określonych powikłań. Niektóre z nich zależą od stosowanej metody operacyjnej i zakładania klipsów.

Cel pracy: Porównanie powikłań po jednoczesnym i oddzielnym podwiązaniu przewodu pęcherzykowego i tętnicy pęcherzykowej oraz ocena kosztów związanych z tymi procedurami.

Materiał i metody: Badanie przeprowadzono z wykorzystaniem prospektywnej kohorty pacjentów. Do analizy włączono chorych z ostrym zapaleniem pęcherzyka żółciowego wywołanym kamicą żółciową. Uczestników podzielono na dwie grupy w zależności od rodzaju podwiązania: 1) oddzielne podwiązanie i 2) jednoczesne podwiązanie. Wykonano rutynowa operację laparoskopową. W pierwszej grupie wypreparowano wnękę oraz oddzielnie podwiązano przewód pęcherzykowy i tętnicę pęcherzykową. W drugiej grupie przeprowadzono jednoczesne podwiązanie przewodu pęcherzykowego i tętnicy pęcherzykowej. Zebrano odpowiednie dane śród-i pooperacyjne. 
Wyniki: Do badania włączono ogółem 122 pacjentów. Mediana czasu od wystapienia objawów do zabiegu chirurgicznego wynosiła 3,23 dnia w grupie z jednoczesnym podwiązaniem i 3,67 dnia w grupie z oddzielnym podwiązaniem $(p=0,004)$. Nie stwierdzono statystycznie istotnej różnicy pod względem powikłań pooperacyjnych. U jednego pacjenta w grupie, w której wykonano jednoczesne podwiązanie, wystąpiła kolka żółciowa i zastój żółci wywołane obecnością złogu w przewodzie żółciowym wspólnym, w związku z czym wykonano zabieg endoskopowej cholangiopankreatografii wstecznej. Pod względem liczby klipsów zastosowanych podczas operacji w grupie z oddzielnym podwiązaniem wykorzystano ich dwukrotnie więcej niż w grupie z jednoczesnym podwiązaniem (6 klipsów vs 3 klipsy, $p \leq 0,001)$. Dalsze analizy wykazały, że czas trwania zabiegu oraz koszty były istotnie wyższe w grupie, w której wykonano oddzielne podwiązanie.

Wnioski: Średni czas trwania operacji był dłuższy, a liczba zastosowanych klipsów większa w grupie oddzielnego podwiązania. Powikłania i skuteczność leczenia w obu badanych grupach były zbliżone. Jednoczesne podwiązanie przewodu pęcherzykowego i tętnicy pęcherzykowej jest metodą efektywną kosztowo, co wskazuje na możliwość zastąpienia rutynowych zabiegów tą techniką w przysłości.

\section{Introduction}

Laparoscopic cholecystectomy is currently recognised as the gold standard in the treatment of symptomatic gallstones [1]. The technique was initially associated with complications such as biliary injury and arterial haemorrhage, but subsequent studies showed fewer complications and lower mortality than open surgery [2-4]. Minor complications of laparoscopic cholecystectomy are managed in a conservative manner. Major complications like vascular or biliary tract injuries are life-threatening and increase the rate of conversion to open surgery [5-7]. As standard, cholecystectomy is performed using an electrosurgical monopolar hook for dissection of adjacent tissues and a clip applier or absorbable clips for cystic duct and cystic artery ligation; other techniques include linear staplers, endo-loops, or sutures, which are rarely used [8]. Unlike ligation with sutures during open surgery, the clips used during laparoscopic surgery are likely to slip, displace, migrate, and perforate the viscera with major bleeding, and rarely embolism. It may also cause cystic duct necrosis, bile leakage, and gallstone formation [9-13]. Routinely, the cystic duct and cystic artery are ligated separately during laparoscopic surgery for acute cholecystitis.

\section{Aim of the research}

The aim of this study is to compare this method with concurrent ligation of cystic duct and artery, especially in patients with high adhesions, and evaluate the complications and cost effectiveness of concurrent ligation.

\section{Material and methods}

This study was designed as a single-centre, prospective cohort and was approved by the Institutional Review Board of Imam Khomeini University Medical Centre. From March 2016 to April 2019, patients older than 18 years presenting to the emergency department with the impression of acute cholecystitis were included. The diagnosis of acute cholecystitis was obtained by considering the right upper quadrant tenderness, temperature higher than $37.5^{\circ} \mathrm{C}$, leukocytosis, and ultrasonography or computed tomography (CT)-scan findings. The exclusion criteria applied were previous upper abdominal surgery, cholangitis, presence of stone in biliary ducts, the risk of conversion to open surgery (due to the situation of the patient, previous abdominal inflammation, etc.), and concomitant cardiovascular complications for which general anaesthesia was contraindicated (Figure 1).

Patients were randomly assigned into 'concurrent ligation' and 'separate ligation' groups. For the first group, the cystic duct and artery were ligated together by hem-o-lok clips at the proximal and distal cystic duct. In the second group, the cystic duct and cystic artery were ligated separately in this manner. Data including age, gender, body mass index (BMI), concomitant medical complications, and time of symptom onset to surgery were collected. Outcomes such as time of the operation, injury to biliary tract, intra-operative bleeding, haematoma or seroma formation, number of applied clips, post-operative pancreatitis and jaundice, re-operation, re-admission rates, and length of stay at hospital were recorded for analysis.

\section{Laparoscopic interventions}

All patients were candidates for laparoscopic cholecystectomy after initial evaluations. In the op-

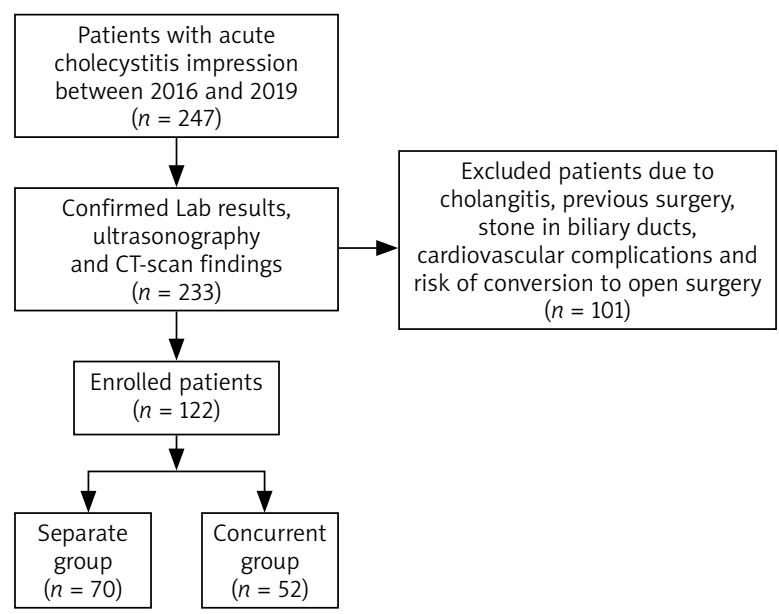

Figure 1. Flow diagram of enrolled patients who underwent cholecystectomy in Imam Khomeini Hospital, Mazandaran University from 2016 to 2019 
Table 1. Patients' characteristics comparing concurrent ligation versus separate ligation in laparoscopic cholecystectomy

\begin{tabular}{|lccc|}
\hline Parameter & $\begin{array}{c}\text { Concurrent ligation } \\
(\boldsymbol{N}=\mathbf{5 2})\end{array}$ & $\begin{array}{c}\text { Separate ligation } \\
(\boldsymbol{N}=\mathbf{7 0})\end{array}$ & $P$-value \\
Female gender, $n(\%)$ & $40(76.9)$ & $59(84.3)$ & 0.304 \\
Age, mean (SD) [years] & $48.96(8.58)$ & $48.90(9.18)$ & 0.948 \\
Body mass index, mean (SD) $\left[\mathrm{kg} / \mathrm{m}^{2}\right]$ & $29.036(3.780)$ & $29.321(3.060)$ & 0.615 \\
Diabetes, $n(\%)$ & $7(13.5)$ & $12(17.1)$ & 0.579 \\
Hypertension, $n(\%)$ & $9(17.3)$ & $10(14.3)$ & 0.649 \\
Cardiac disease, $n(\%)$ & $4(7.7)$ & $5(7.1)$ & 0.909 \\
$\begin{array}{l}\text { Length of time from onset of symptoms to surgery, } \\
\text { mean (SD) [days] }\end{array}$ & $3.23(0.730)$ & $3.67(0.846)$ & 0.004 \\
\hline
\end{tabular}

erating room, they were placed in a supine position. Anaesthesia was induced by midazolam $(300 \mu \mathrm{g} / \mathrm{kg})$ and fentanyl $(2 \mu \mathrm{g} / \mathrm{kg})$. Anaesthesia was maintained by sevoflurane $\left(0.9 \%\right.$ with $\left.65 \% \mathrm{~N}_{2} \mathrm{O} / 35 \% \mathrm{O}_{2}\right)$, atracurium $(0.01 \mathrm{mg} / \mathrm{kg} / \mathrm{min})$, and propofol $(0.2 \mathrm{mg} / \mathrm{kg} /$ min). After induction of anaesthesia, an endotracheal tube was inserted. A nasogastric tube was also inserted to drain the secretions and compress the stomach. A single $2 \mathrm{~cm}$ incision was made in the upper edge of the umbilicus. Pneumoperitoneum was created with insufflation of carbon dioxide by a Verres needle. Then a 10-mm trocar was inserted through this incision. The laparoscopic camera was inserted and three additional ports (one $10 \mathrm{~mm}$ and two $5 \mathrm{~mm}$ ) were placed under direct vision. The gallbladder fundus was retracted over the edge of the liver. Adhesions in hilar area were released by blunt dissection. Further dissections were performed using an electrocautery hook to achieve the triangle of Calot. After identification of the cystic artery, cystic duct, and common bile duct, a hem-o-lok clip was placed on the distal cystic duct. In the 'concurrent ligation' group, the surgeon did not perform the dissection of cystic duct and artery because of adhesions and inflammation of these components. Then two clips were placed in a way that proximal cystic duct and cystic artery were ligated together. In the 'separate ligation' group, two clips were placed on the proximal cystic duct and the duct was divided. Cystic artery was divided in this manner. The gallbladder was dissected out of the gallbladder fossa by hook cautery. Haemostasis of the inferior surface of the liver was achieved. Finally, the gallbladder was removed via supra-umbilical incision. The gallbladder was removed by endo-bag when it was inflamed or gangrenous. The ports were removed, and a drain was inserted through one of incisions only when necessary to ensure liver homeostasis. After deflation of peritoneum, skin was closed by $4 / 0$ Prolene sutures. A total of six clips for each patient in the separate ligation group and three clips for those in the concurrent group were used.

\section{Statistical analysis}

Descriptive quantitative data were computed while calculating the mean and standard deviation or median and quadratic range as well as qualitative data describing the frequency and percentage. Statistical comprising the $\chi^{2}$, Fisher's exact test, Mann-Whitney $U$-test, and Student's $t$-test were applied to analyse the data obtained from the study groups. The Statistical Package for the Social Sciences (SPSS, version 21.0; IBM, USA) was used for data analysis. A two-sided $p$-value of $<0.05$ was considered as the significance level.

\section{Results}

A total of 122 patients who underwent laparoscopic cholecystectomy for acute cholecystitis were enrolled in this study. A summary of patients' characteristics is given in Table 1. Concurrent ligation performed for 52 patients, and 70 patients underwent routine ligation. Median age at the time of surgery was 48.96 \pm 8.58 years for the concurrent ligation group and $48.90 \pm 9.18$ years for the separate ligation group. Nineteen patients had a history of diabetes. Nineteen patients had hypertension, and cardiac problems were reported in nine patients. From the anaesthesiologist's point of view, cardiovascular complications of these patients were such that they had no contraindication for laparoscopic surgery.

The median length of time from symptoms to surgery was 3.23 days for the concurrent ligation group versus 3.67 days for the separate ligation group $(p=0.004)$. Total of seven patients were re-admitted during the study due to upper abdominal pain after surgery $(9.6 \%$ in the concurrent ligation group vs. $2.9 \%$ in the separate ligation group, $p=0.135$ ). There was no statistically significant difference in post-operative complications. One patient in the concurrent ligation group had biliary colic and cholestasis due to a stone in common bile duct (CBD), which was managed by endoscopic retrograde cholangiopan- 
Table 2. All intra-operative and post-operative complications, number of clips used, length of operation, and length of stay at hospital

\begin{tabular}{|c|c|c|c|}
\hline Parameter & $\begin{array}{l}\text { Concurrent ligation } \\
\qquad(N=52)\end{array}$ & $\begin{array}{l}\text { Separate ligation } \\
\qquad(N=70)\end{array}$ & $P$-value \\
\hline Readmission following upper abdominal pain, $n(\%)$ & $5(9.6)$ & $2(2.9)$ & 0.135 \\
\hline Re-operation (ERCP), $n$ (\%) & $1(1.9)$ & $0(0)$ & 0.426 \\
\hline Post-op. jaundice, $n$ (\%) & $0(0)$ & $0(0)$ & - \\
\hline Post-op. pancreatitis, $n$ (\%) & $0(0)$ & $1(1.4)$ & 0.20 \\
\hline Haematoma, $n(\%)$ & $0(0)$ & $0(0)$ & - \\
\hline Intra-operative haemorrhage, $n$ (\%) & $0(0)$ & $0(0)$ & - \\
\hline Biliary duct injury, $n$ (\%) & $0(0)$ & $0(0)$ & - \\
\hline Number of clips, $n(\%)$ : & & & $\leq 0.001$ \\
\hline 3 clips in each patient & $52(100)$ & $0(0)$ & \\
\hline 6 clips in each patient & $0(0)$ & $70(100)$ & \\
\hline Total & $156(27)$ & $420(73)$ & \\
\hline Costs of clips & $78,000,000$ IRR & $210,000,000$ IRR & $\leq 0.001$ \\
\hline Total length of operation, mean (SD) [min] & $58.46(11.77)$ & $67.43(12.09)$ & $\leq 0.001$ \\
\hline Total hospital length of stay, mean (SD) [days] & $3.519(0.99)$ & $3.157(0.879)$ & 0.022 \\
\hline
\end{tabular}

creatography (ERCP). One patient in the separate ligation group developed post-operative pancreatitis treated with antibiotics and intravenous fluids. Complications including conversion to open surgery, biliary duct injury, haematoma, jaundice, and intraoperative haemorrhage did not occur during this study.

After dissection of hilum and visualisation of cystic duct and cystic artery, three and six hem-o-lok clips were used for each patient in concurrent and separate ligation groups, respectively ( $p \leq 0.001)$. Given the price of 500,000 IRR (about 12 USD) for each hem-o-lok clip, the total price of the clips was $78,000,000$ IRR (1857 USD) for the concurrent ligation group and 210,000,000 (5000 USD) for the separate ligation group $(p \leq 0.001)$. The overall operation time was significantly higher in the separate ligation group (67.43 min vs. 58.46 for the concurrent ligation group, $p \leq 0.001)$. Median total length of stay in the hospital was 3.157 and 3.519 days for separate and concurrent ligation groups, respectively ( $p=0.022$, Table 2$)$.

\section{Discussion and conclusions}

The results of this study show that the mean duration of surgery in the separate ligation group was significantly longer than for the concurrent ligation group. Also, the number of clips used in the separate ligation group was greater than in the concurrent ligation group. No complications were seen during surgery, including bleeding and bile duct injury. Postoperative jaundice, haematoma, and seroma formation were not reported in any patient. There were no significant differences between the two groups in other complications such as pancreatitis, readmission due to abdominal pain, or reoperation. In a systematic review of complications after laparoscopic cholecystectomy by Alexander et al. including 967 complications in 233 studies, conversion to open surgery was the most commonly reported complication (58\%). Bile leak (38\%) and bile duct injuries (38\%) were the most common complications after that [14]. In our study, none of the laparoscopic procedures was converted to open surgery. Patients with higher risk of conversion to open surgery (such as previous upper abdominal surgery or inflammation) were excluded from this study. Also, biliary tracts were not injured in any patient during surgery. Terho et al. and Botaitis et al. both demonstrated that conversion to open surgery is associated with gallbladder gangrene or abscess. The other risk factors included diabetes, age $>65$ years, or previous upper abdominal surgery. Also, fever and high levels of C-reactive protein (CRP) were associated with this complication $[15,16]$. In other study by Nagaoka et al. it was shown that higher incidence of complications was expected if the interval between the onset of cholecystitis symptoms and surgery was longer than 72 h. Further analyses demonstrated that elevated serum CRP and heavy intra-operative blood loss could develop post-operative complications [17]. In the present study, the median length of time from symptom onset to surgery was 3.23 and 3.67 days in the concurrent and separate ligation groups, respectively. Intra-operative massive haemorrhage and postoperative haematoma were not reported in patients. However, 1 patient in the concurrent ligation group 
had post-operative cholestasis symptoms due to a stone in the CBD. This case was managed by ERCP. Previous studies showed that delayed laparoscopic operations that take more than $48 \mathrm{~h}$ from the onset of symptoms are associated with higher conversion rates, post-operative complications, longer stay in the hospital, and higher hospital costs. Laparoscopic surgery within $24 \mathrm{~h}$ was shown to be associated with fewer complications and conversion rates. However, there was no significant correlation between the waiting time to surgery and the mortality rate [18-20]. Some complications of laparoscopic cholecystectomy are due to the nature of the surgery itself. The study of Yano et al. indicated that applying absorbable clips is associated with lower rates of conversion to open surgery than metal clips. Operative time and length of stay in the hospital were also lowered by using absorbable clips [8]. Although patients in the concurrent ligation group had shorter length of operation and lower cost of clips, the length of stay in the hospital was greater for them (but not significantly).

Overall, the number of clips used in the separate ligation group was twice that of the concurrent ligation group (six clips for each patient in the separate ligation group vs. three clips for those in the concurrent ligation group) in present study. To put it simply, the costs of the clips in the concurrent group were half that of the other group for each patient, and also the duration of surgery was shorter for them. In laparoscopic cholecystectomy, the costs of operation depend on the surgeon. The surgeon's decision for using equipment and cost-saving strategies can affect the supply costs in the long term [21, 22].

This study has several limitations. To our knowledge, except for a few reports with different methods in open cholecystectomy, there is no study with a method similar to ours that could compare the results. Despite the shorter operation time and cost of clips in the concurrent ligation group, the duration of hospital stay was longer. In this regard, we did not compare the two groups regarding overall costs of hospital stay. We recommend further studies with larger populations to compare the total hospital charges, not just the operating costs. The differences between these two methods of ligation in terms of intra-operative and post-operative complications, length of stay in the hospital, and mortality were not statistically significant. However, concurrent ligation has a shorter surgical duration, and fewer clips were used in this method. Laparoscopic cholecystectomy with concurrent ligation of the cystic duct and artery seems to be associated with similar complications and therapeutic outcomes compared to separate ligation (routine procedure) in acute cholecystitis with high adhesions and inflammation. It is cost-effective and could replace the routine procedure in the future.

\section{Conflict of interest}

The authors declare no conflict of interest.

\section{References}

1. Nagral S. Anatomy relevant to cholecystectomy. J Minim Access Surg 2005; 1: 53-8.

2. Larobina M, Nottle P. Complete evidence regarding major vascular injuries during laparoscopic access. Surg Laparosc Endosc Percutan Techn 2005; 15: 119-123.

3. Tebala GD, Innocenti P, Ciani R, Zumbo A, Fonsi GB, Bellini P, De Chiara F, Fittipaldi D, Hadjiamiri H, Lamaro S, Marinoni R. Identification of gallbladder pedicle anatomy during laparoscopic cholecystectomy. Chirur Ital 2004; 56: 389-396.

4. Jatzko GR, Lisborg PH, Pertl AM, Stettner HM. Multivariate comparison of complications after laparoscopic cholecystectomy and open cholecystectomy. Ann Surg 1995; 221: 381-386.

5. McKinley SK, Brunt LM, Schwaitzberg SD. Prevention of bile duct injury: the case for incorporating educational theories of expertise. Surg Endosc 2014; 28: 3385-3391.

6. Fuller J, Ashar B, Carey-Corrado J. Trocar-associated injuries and fatalities: an analysis of 1399 reports to the FDA. J Minim Invasive Gynecol 2005; 12: 302-307.

7. Nair RG, Dunn DC, Fowler S, McCloy RF. Progress with cholecystectomy: improving results in England and Wales. Br J Surg 1997; 84: 1396-1398.

8. Yano H, Okada K, Kinuta M, Nakano Y, Tono T, Matsui S, Iwazawa T, Kanoh T, Monden T. Efficacy of absorbable clips compared with metal clips for cystic duct ligation in laparoscopic cholecystectomy. Surg Today 2003; 33: 18-23.

9. Westervelt J. Clipless cholecystectomy: broadening the role of the harmonic scalpel. JSLS 2004; 8: 283-285.

10. Ammann K, Kiesenebner J, Gadenstatter M, Mathis G, Stoss F. Embolism of a metallic clip: an unusual complication following laparoscopic cholecystectomy. Dig Surg 2000; 17: 542-544.

11. Wise Unger S, Glick GL, Landeros M. Cystic duct leak after laparoscopic cholecystectomy. A multi-institutional study. Surg Endosc 1996; 10: 1189-1193.

12. Ghavidel A. Migration of clips after laparoscopic cholecystectomy; a case report and literature review. Middle East J Dig Dis 2015; 7: 45-49.

13. Chong VH, Yim HB, Lim CC. Clip-induced biliary stone. Singapore Med J 2004; 45: 533-535.

14. Alexander HC, Bartlett AS, Wells CI, Hannam JA, Moore MR, Poole GH, Merry AF. Reporting of complications after laparoscopic cholecystectomy: a systematic review. HPB 2018; 20: 786-794.

15. Terho PM, Leppaniemi AK, Mentula PJ. Laparoscopic cholecystectomy for acute calculous cholecystitis: a retrospective study assessing risk factors for conversion and complications. World J Emerg Surg 2016; 11: 54.

16. Botaitis S, Pitiakoudis M, Perente S, Tripsianis G, Polychronidis A, Simopoulos C. Laparoscopic cholecystectomy in acute cholecystitis: an analysis of the risk factors. South African J Surg 2012; 50: 62-70.

17. Nagaoka T, Watanabe J, Nakagawa Y, Ishida N, Imai Y, Nezu K. Analysis of the risk factors for postoperative complications in laparoscopic cholecystectomy for acute cholecystitis. Nihon Rinsho Geka Gakkai Zasshi 2016; 77: 739-745. 
18. Chandler CF, Lane JS, Ferguson P, Thompson JE, Ashley SW. Prospective evaluation of early versus delayed laparoscopic cholecystectomy for treatment of acute cholecystitis. Am Surgeon 2000; 66: 896-900.

19. Banz V, Gsponer T, Candinas D, Guller U. Population-based analysis of 4113 patients with acute cholecystitis: defining the optimal time-point for laparoscopic cholecystectomy. Ann Surg 2011; 254: 964-970.

20. Roulin D, Saadi A, Di Mare L, Demartines N, Halkic N. Early versus delayed cholecystectomy for acute cholecystitis, are the 72 hours still the rule? A randomized trial. Ann Surg 2016; 264: 717-722.

21. Brauer DG, Hawkins WG, Strasberg SM, Brunt LM, Jaques DP, Mercurio NR, hall BL, Fields RC. Cost variation in a laparoscopic cholecystectomy and the association with outcomes across a single health system: implications for standardization and improved resource utilization. HPB 2015; 17: 1113-1118.

22. Slater M, Booth MI, Dehn TCB. Cost-effective laparoscopic cholecystectomy. Ann R Coll Surg Engl 2009; 91: 670-672.

\section{Address for correspondence:}

Sohrab Sayadi

Department of General Surgery

Imam Khomeini Hospital Gastrointestinal Cancer Research

Center, W Mazandaran University of Medical Sciences

Sari, Iran

E-mail: academicpublishingg@gmail.com 